Mini Review

\title{
Quartz Crystal Microbalance (QCM) Sensing Materials in Biosensors Development
}

\author{
Miroslav Pohanka \\ Faculty of Military Health Sciences, University of Defence, Trebesska 1575, CZ-500 01 Hradec \\ Kralove, Czech Republic \\ E-mail: miroslav.pohanka@gmail.com
}

Received: 27 August 2021 / Accepted: 13 September 2021 / Published: 10 November 2021

\begin{abstract}
Quartz crystal microbalance (QCM) biosensors are a type of analytical devices working on piezoelectric principle. The piezoelectric biosensors are different in their principle to the other types of biosensors, namely the voltametric and optical one because they measure a mass attached on their surface. It makes them readily for label free assays and construction of analytical devices where simplicity is expected and label free design is beneficial. Field assays and point of care tests are typical ways how a QCM based sensor will be applied in the praxis. On the other hand, the assays can exert significant specifications and be suitable for laboratory purposes. In this review, principle of piezoelectricity and QCM are explained and the recent applications of QCM in biosensors construction are described.
\end{abstract}

Keywords: affinity interactions; antibody; bioassay; immunoassay; immunosensor; label free assay; piezoelectricity; point-of-care test; quartz

\section{$\underline{\text { FULL TEXT }}$}

(C) 2021 The Authors. Published by ESG (www.electrochemsci.org). This article is an open access article distributed under the terms and conditions of the Creative Commons Attribution license (http://creativecommons.org/licenses/by/4.0/). 